\title{
OPEM
}

www.opem.org

Oriental Pharmacy and Experimental Medicine 2009 9(2), 149-156

DOI 10.3742/OPEM.2009.9.2.149

\section{Anti-inflammatory effect of Equisetum hyemale via suppression of nuclear factor- $\kappa B$ activation in human mast cells}

\author{
So-Ra Jeon ${ }^{1}$, Ho-Jeong $\mathrm{Na}^{2}$ and Hoon Jeon ${ }^{1,3, *}$ \\ ${ }^{I}$ Department of Oriental Pharmacy. College of Pharmacy, Woosuk University, Chonbuk, Republic of Korea; \\ ${ }^{2}$ Department of Medicine, Division of Allergy and Clinical Immunology, Johns Hopkins University School of \\ Medicine, Johns Hopkins Asthma Center, Baltimore, Maryland, USA; ${ }^{3}$ Center for Healthcare Technology \\ Development, Republic of Korea
}

Received for publication April 20, 2009; accepted June 10, 2009

\section{SUMMARY}

Equisetum hyemale Linne. (EH) (Equisetaceae) has been used for the treatment of eye and skin disease, chronic eczema, pneumoconiosis and asthma in Korea and China. Human leukemic mast cells are widely distributed in the connective tissues of mammals and other vertebrates. Phorbol 12-myristrate 13-acetate (PMA) and calcium ionophore A23187 stimulated Human leukaemic mast cell line-1 (HMC-1) can produce a variety of inflammatory mediators and several proinflammatory and chemotactic cytokines such as TNF- $\alpha$, IL- 6 and IL- 8 . Since TNF- $\alpha$, IL- 6 and IL-8 are major factors during the inflammatory process, we studied the effects of EH on TNF- $\alpha$, IL-6 and IL-8 release in HMC-1 stimulated with PMA and A23187. The result of this study indicate that EH inhibits TNF- $\alpha$, IL-6 and IL-8 in activated HMC-1 cells via IкB/Nuclear factor-kB pathway. Therefore, EH might contribute significantly to the prevention or treatment of mast-cell mediated inflammatory diseases and $\mathrm{EH}$ has potential use in the therapy of chronic allergic inflammation.

Key words: Equisetum hyemale; TNF- $\alpha$; IL-6; IL-8; NF-кB

\section{INTRODUCTION}

A whole part of Equisetum hyemale Linne. (EH) has been used for the treatment of eye and skin disease, a sore throat, an anal prolapse, an abscess, chronic eczema, pneumoconiosis and asthma. EH has canes of joint and lives in swampy land (Lee $e t$ al., 1995).

Human mast cells broadly distributed in mammalian tissues are fascinating, multifunctional,

\footnotetext{
*Correspondence: Hoon Jeon, Department of Oriental Pharmacy, College of Pharmacy, Woosuk University, Chonbuk, Republic of Korea. Tel: +82632901577; Fax: +82632901576; E-mail: hna4@jhmi.edu
}

tissue-dwelling cells and one of the major effector cells in inflammatory reactions (Galli et al., 1994; Krishnaswamy et al., 2006). The binding of antigens to receptor-bound IgE and the subsequent crosslinking of the high-affinity $\operatorname{IgE}$ receptor (FceRI) is the classical trigger of mast cell activation. Activated mast cells exert their biologic effects by releasing preformed and novo-synthesized mediators such as histamine, proteases, leukotrienes, prostagrandins and cytokines. Chemokines and proinflammatory cytokines, including TNF- $\alpha$, IL-6 and IL-8 promote the development of inflammatory reaction (Beaven and Metzger, 1993; Galli, 1993; Church and Levi-Schaffer, 1997; Metcalfe et al., 
1997; Kim and Lee, 1999). TNF- $\alpha$ induces tissue damage and is considered a major initiator of inflammation (Kim and Lee, 1999). IL-6 is a proinflammatory cytokine that is a potent mediator of inflammatory processes (Ershler and Keller, 2000). IL-8 is a potent neutrophil chemoattractant factor (Annelie et al., 1993).

NF- $\kappa \mathrm{B}$ is a imperative transcription factor. NF$\kappa B$ dimeric complexes composed of Rel A (p65), NFêB1 (p50) or NFkB2 (p52) subunits are normally associated with inhibitory IкB protein $(\alpha, \beta, \gamma)$ in the cytoplasm in an inactive state (Grimm and Baeuerle, 1993; Baeuerie and Henkel, 1994). When the cells are stimulated by extracellular stimuli, specific kinases lead to the degradation and phosphorylation of IאB and activation of NF-KB (Baeuerie and Henkel, 1994; Baumgartner et al., 1994). The activated NF- $\mathrm{kB}$ translocates to the nucleus, binds the DNA, activates inflammatory genes and finally transcribes the mediator such as TNF- $\alpha$, IL- 6 and IL-8 (Collart et al., 1990; Rao, 1994; Baumgartner et al., 1994; Thanos and Maniatis, 1995; Azzolina et al., 2003).

Although EH has been widely used for the treatment of inflammation in Korea and China, the effects of EH on inflammatory molecules in mast cell have not been studied sufficiently. To investigate the anti-inflammatory effect of $\mathrm{EH}$, this report examined the effects of EH on TNF- $\alpha$, IL- 6 and IL-8

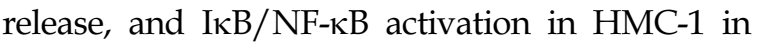
response to PMA and the A23187.

\section{MATERIALS AND METHODS}

\section{Reagents}

Iscove's Modified Dulbecco's Medium (IMDM), penicillin and streptomycin were purchased from Gibco BRL (Grand Island, NY, USA). PMA, calcium ionophore A23187, diphenyltetrazolium bromide (MTT), avidin-peroxidase and 2,2-azio-bis (ABTS) were purchased from the Sigma Chemical Co. (St. Louis, MO, USA). Recombinant TNF- $\alpha$ and biotinylated anti-human TNF- $\alpha$ were purchased from R\&D system Inc. (Minneapolis, MN, USA). Recombinant IL-6 and IL-8, biotinylated anti-human IL-6 and IL-8 were purchased from Pharmingen (San Diego, CA, USA). NF-kB antibody was purchased from Santa Cruz Biotechnology (Santa Cruz, CA, USA).

\section{Preparation of EH}

EH was purchased from Wansanyakupsa (Jeonju, South Korea) in March 2005. A voucher specimen (WME039) has been deposited at the Department of Oriental Pharmacy, College of Pharmacy, Woosuk University. An extract was obtained twice from the dried sample (200 g) with 3,000 $\mathrm{ml}$ of $85 \% \mathrm{MeOH}$ under ultrasonification fo $2 \mathrm{~h}$. It was evaporated and lyophilized to yield $(1.9 \mathrm{~g})$ an $\mathrm{MeOH}$ extract of EH (Yield : 4.185\%), which was then stored at $-20^{\circ} \mathrm{C}$ until use.

\section{Cell culture and stimulation of mast cells}

HMC-1 was cultured in IMDM (Gibco, Co.) supplemented with $10 \%$ heat-inactivated fetal bovine serum, $100 \mathrm{U} / \mathrm{ml}$ of penicillin, and $0.1 \mathrm{mg} / \mathrm{ml}$ of streptomycin and maintained in a humidified incubator with 5\% $\mathrm{CO}_{2}$. HMC-1 was passaged 2-3 times per week with 1:2 split ratio. For ELISA, HMC-1 was stimulated with PMA $(50 \mathrm{nM})$ and A23187 $(1 \mu \mathrm{M})$ for $24 \mathrm{~h}$ after the treatment of EH for $30 \mathrm{~min}$. For western blotting, HMC-1 was also stimulated with PMA (50 nM) and A23187 $(1 \mu \mathrm{M})$ for $1 \mathrm{~h}$ after the treatment of $\mathrm{EH}$ for $30 \mathrm{~min}$.

\section{Cell viability assay (MTT assay)}

The effects of cytotoxicity in HMC-1 treated with final concentrations of $0.1,0.5$ and $1 \mathrm{mg} / \mathrm{ml}$ of $\mathrm{EH}$ extract was evaluated using a colorimetric MTTassay, which measured the ability of viable cells to reduce the colorless tetrazolium salt MTT to the colored formazan product. The HMC-1 cells were treated with final concentrations of $0.1,0.5$ and $1 \mathrm{mg} / \mathrm{ml}$ of EH extract for $24 \mathrm{~h}$ at $37^{\circ} \mathrm{C}$. Following this incubation period, the $50 \mu \mathrm{l}$ of MTT solution $(5 \mathrm{mg} / \mathrm{ml})$ was added each well. After $3 \mathrm{~h}$ of 
incubation, the MTT formazan products were solubilized with DMSO. Absorbance of the colored solution was measured at $570 \mathrm{~nm}$.

\section{Enzyme-linked immunosorbent assay (ELISA)}

HMC-1 $\left(3 \times 10^{5}\right.$ cells/well) and was cultured in the absence or in the presence of $0.1,0.5 \mathrm{and} 1 \mathrm{mg} / \mathrm{ml}$ of $\mathrm{EH}$ and stimulated with PMA $(50 \mathrm{nM})$ and A23187 $(1 \mu \mathrm{M})$ for $24 \mathrm{~h}$. We then used ELISA method to assay the culture supernatants for the TNF- $\alpha$, IL- 6 and IL-8 protein levels. To measure the cytokines, we used a modified ELISA method (Moon et al., 2007). Color development was measured at $405 \mathrm{~nm}$ using an automated microplate ELISA reader.

\section{Cytoplasmic and nuclear protein extraction}

HMC- 1 was plated at $5 \times 10^{6}$ cells in 60 -mm dishes. After the cells were treated with final concentrations of $0.1,0.5$ and $1 \mathrm{mg} / \mathrm{ml}$ of $\mathrm{EH}$ extract for $30 \mathrm{~min}$, stimulated with PMA $(50 \mathrm{nM})$ and A23187 $(1 \mu \mathrm{M})$ for $1 \mathrm{~h}$. The cells were scraped, washed twice with PBS, and resuspended in hypotonic buffer A (10 nM HEPES/KOH, $2 \mathrm{mM} \mathrm{MgCl} 2,0.1 \mathrm{mM}$ EDTA, $10 \mathrm{mM} \mathrm{KCl}, 1 \mathrm{mM}$ dithiothreitol and $0.5 \mathrm{mM}$ phenylmethylsulfonyl fluoride, $\mathrm{pH}$ 7.9) and incubated on ice for $30 \mathrm{~min}$. After NP-40 were added and the cells were incubated on ice for $10 \mathrm{~min}$, the supernatant from the centrifugation $\left(2500 \mathrm{rpm}, 20 \mathrm{~min}, 4^{\circ} \mathrm{C}\right)$ of this mixture was collected as cytoplasmic protein. For the removal of residual cytoplasmic protein, the nuclear pellet was washed in hypertonic buffer (50 nM HEPES/KOH, $50 \mathrm{mM} \mathrm{KCl,} 300 \mathrm{mM} \mathrm{NaCl}$, $0.1 \mathrm{mM}$ EDTA, $10 \%$ glycerol, $1 \mathrm{mM}$ dithiothreitol and $0.5 \mathrm{mM}$ phenylmethylsulfonyl fluoride, $\mathrm{pH}$ 7.9). The supernatant from the centrifugation $(12,000$ $\mathrm{rpm}, 5 \mathrm{~min}, 4^{\circ} \mathrm{C}$ ) of this mixture was collected as nuclear protein.

\section{Western blotting assay}

Cellular protein were extracted by a detergent lysis procedure. The $60-\mathrm{mm}$ dishes of HMC-1 cells $(5 \times$ $10^{6}$ cells) were scraped. Samples were heated at 95 for $5 \mathrm{~min}$, and the cell extracts were separated by $10 \%$ SDS-PAGE and transferred onto nitrocellulose membranes (Hybond-C extra, Amersham, GB) by the semi-dry procedure. Blots were blocked overnight with $5 \%$ milk powder and probed with the NF- $\mathrm{KB}$ and phosphate IкB antibodies (Santa cruz, CA, USA) for $2 \mathrm{~h}$. The mouse anti-rabbit IgG antibody and anti-mouse IgG antibody was incubated for $90 \mathrm{~min}$ at room temperature, respectively, then staining visualized by the enhanced chemiluminescence technique (Pierce, USA), and exposure to X-ray film (Fuji, Tokyo, Japan)

\section{Statistics}

The data are shown as mean \pm S.E.M. Statistical significance was determined by student's $t$-test, and $P<0.05$ was considered significantly.

\section{RESULTS}

\section{Effect of EH on cytotoxicity in HMC-1 cells}

In order to examine cytotoxic effect of EH, MTT assay was performed in HMC-1. The HMC-1 was pre-treated with final concentrations of $0.1,0.5$ and $1 \mathrm{mg} / \mathrm{ml}$ of EH for $24 \mathrm{~h}$. After incubating for $24 \mathrm{~h}$, cell viability was measured by the method described above. As shown in Fig. 1, the concentrations of 0.1,

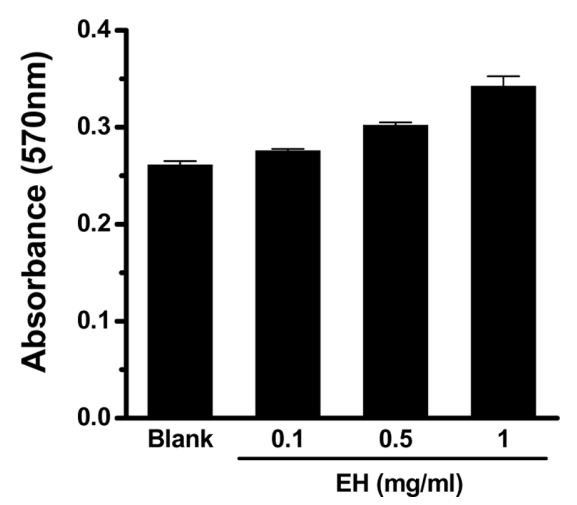

Fig. 1. Effect of EH on the cell viability on HMC-1 cells. Cell viability was evaluated by MTT assay $24 \mathrm{~h}$ after $\mathrm{EH}$ treatment as indicated concentrations in HMC-1 cells. Each data represents the mean \pm S.E.M. of three independent experiments. 


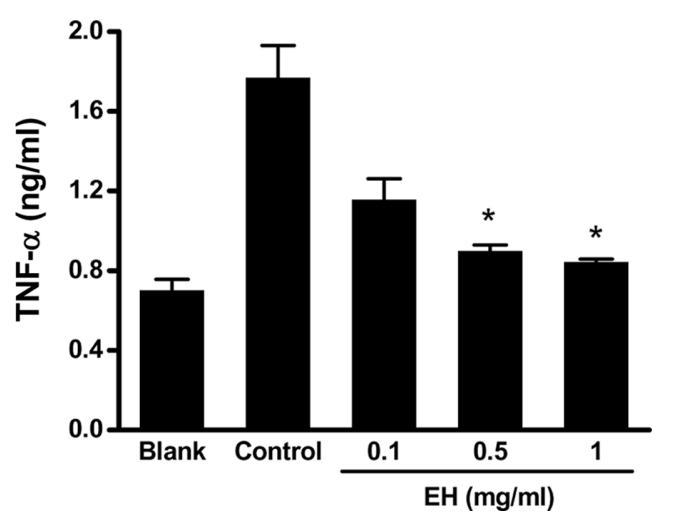

Fig. 2. Effect of EH on TNF- $\alpha$ expression in PMA and A23187 stimulated HMC-1 cells. Cells were pretreated with $\mathrm{EH}$ for $30 \mathrm{~min}$ prior to PMA ( $50 \mathrm{nM})$ and A23187 $(1 \mu \mathrm{M})$ stimulation for $24 \mathrm{~h}$. TNF- $\alpha$ concentrations were measured from cell supernatants using ELISA method. Values are expressed as mean \pm S.E.M. of three independent experiments.

0.5 and $1 \mathrm{mg} / \mathrm{ml}$ of EH had little effect on the cell viability.

\section{Effect of EH on TNF- $\alpha$ release}

As the most important pro-inflammatory cytokines in mast cell mediated inflammation, TNF- $\alpha$, IL-6 and IL-8 were assayed essentially and generally. To investigate the effect of $\mathrm{EH}$ on TNF- $\alpha$ release from HMC-1, culture supernatant treated with final concentrations of $0.1,0.5$ and $1 \mathrm{mg} / \mathrm{ml}$ of $\mathrm{EH}$ were assayed for TNF- $\alpha$ cytokine level by ELISA methods. Fig. 2 showed that EH inhibited the release of TNF- $\alpha$ in PMA and A23187 stimulated HMC-1 in a dose-dependant manner significantly.

\section{Effect of EH on IL-6 release}

To investigate the effect of EH on IL-6 release from HMC-1, culture supernatant treated with final concentrations of $0.1,0.5$ and $1 \mathrm{mg} / \mathrm{ml}$ of $\mathrm{EH}$ were assayed for IL- 6 cytokine level by ELISA methods. Fig. 3 showed that EH inhibited the release of IL-6 in PMA and A23187 stimulated HMC-1 in a dosedependant manner, especially in $1 \mathrm{mg} / \mathrm{ml}$ of $\mathrm{EH}$.

\section{Effect of EH on IL-8 release}

To investigate the effect of EH on IL-8 release from

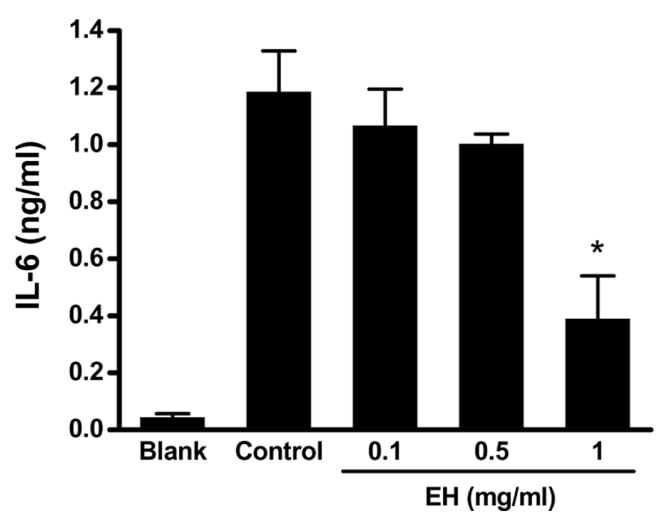

Fig. 3. Effect of EH on IL-6 expression in PMA and A23187 stimulated HMC-1 cells. Cells were pretreated with EH for $30 \mathrm{~min}$ prior to PMA ( $50 \mathrm{nM}$ ) and A23187 $(1 \mu \mathrm{M})$ stimulation for $24 \mathrm{~h}$. IL-6 concentrations were measured from cell supernatants using ELISA method. Values are expressed as mean \pm S.E.M. of three independent experiments.

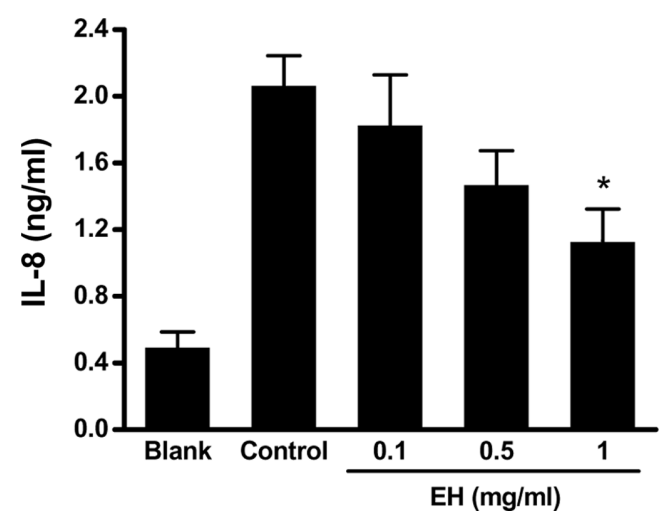

Fig. 4. Effect of EH on IL-8 expression in PMA and A23187 stimulated HMC-1 cells. Cells were pretreated with EH for $30 \mathrm{~min}$ prior to PMA ( $50 \mathrm{nM}$ ) and A23187 $(1 \mu \mathrm{M})$ stimulation for $24 \mathrm{~h}$. IL-8 concentrations were measured from cell supernatants using ELISA method. Values are expressed as mean \pm S.E.M. of three independent experiments.

HMC-1, culture supernatant treated with final concentrations of $0.1,0.5$ and $1 \mathrm{mg} / \mathrm{ml}$ of $\mathrm{EH}$ were assayed for IL-8 cytokine level by ELISA methods. Fig. 4 showed that EH inhibited the release of IL-8 in PMA and A23187 stimulated HMC-1 cells in a dose-dependant manner.

\section{Effect of EH on the IêB degradation}

The release of TNF- $\alpha$, IL- 6 and IL- 8 was regulated 


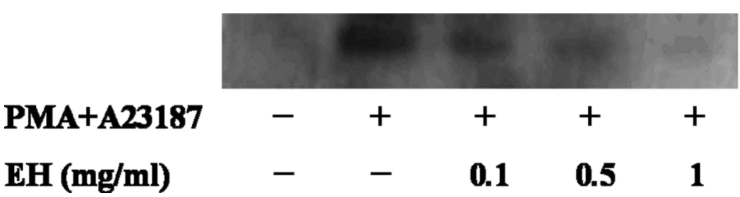

Fig. 5. Effect of $\mathrm{EH}$ on the expression of phosphate I $\mathrm{BB} \alpha$ in PMA and A23187 stimulated HMC-1 cells. Cells were pretreated with $\mathrm{EH}$ for $30 \mathrm{~min}$ prior to PMA (50 nM) and A23187 $(1 \mu \mathrm{M})$ stimulation for $1 \mathrm{~h}$. Expression of phosphate I $\mathrm{BB} \alpha$ is assayed by western blot analysis.

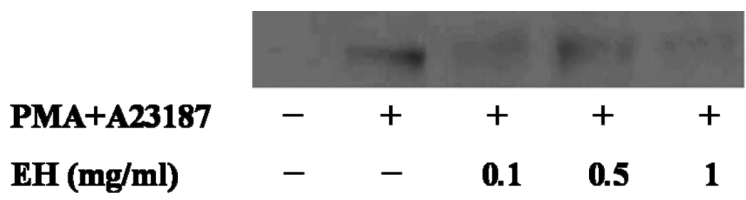

Fig. 6. Effect of EH on the expression of p65 NF- $\mathrm{BB}$ in PMA and A23187 stimulated HMC-1 cells. Cells were pretreated with $\mathrm{EH}$ for 30 min prior to PMA (50 $\mathrm{nM})$ and A23187 $(1 \mu \mathrm{M})$ stimulation for $1 \mathrm{~h}$. Expression of nucleus NF- $\mathrm{B}$ is assayed by western blot analysis.

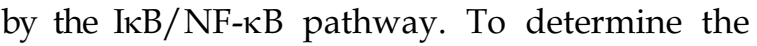
effect of $\mathrm{EH}$ on the expression of inhibitor phosphate IKB, we performed a western blot analysis for phosphate IкB in HMC-1 stimulated by PMA and A23187. In PMA plus A23187stimulated cells, the expression level of phosphate IкB $\alpha$ increased in the cytoplasm. However, Fig. 5 showed that the expression level of phosphate IкB $\alpha$ decreased by treatment of $\mathrm{EH}$ in a dose-dependant manner.

\section{Effect of EH on the NF-kB activation}

To determine the effect of $\mathrm{EH}$ on the expression of $\mathrm{NF}-\mathrm{\kappa B}$, this report performed a western blot analysis for p65 protein in HMC-1 stimulated by PMA and A23187. In PMA plus A23187-stimulated cells, the expression level of NF- $\mathrm{KB}$ increased in the nucleus. However, Fig. 6 showed that the expression level of NF-kB decreased by treatment of EH remarkably. The result of treatment in $0.5 \mathrm{mg} / \mathrm{ml}$ of $\mathrm{EH}$ is no supposed blot, and further study is necessary to obtain the clarified outcome.

\section{DISCUSSION}

Mast cells are fascinating, multifunctional, tissuedwelling cells that have been traditionally associated with the allergic response. However, recent studies suggest these cells may be capable of regulating inflammation (Krishnaswamy et al., 2006). Mast cells activated by PMA and A23187 are useful in vitro model system for studying of multifunctional effects of the immune and inflammatory reaction (Hosoda et al., 2002; Kim et al., 2003). Mast cells contain preformed and potent allergic inflammatory mediators such as histamine, heparin, proteinases, leukotriense and multifuctional cytokines (Jeong et al., 2006).

The cytokines especially TNF- $\alpha$, IL- 6 and newly synthesized IL-8 are key indicators of inflammatory symptom for the reason of critical biological role in inflammation and matrix degradation (Tetlow and Woolley, 1995; Galli et al., 2005). TNF- $\alpha$ is released as a prestored but also newly synthesized cytokine upon cell activation in mast cells (Hide et al., 1997). TNF- $\alpha$ promotes inflammation, leukocyte infiltration, granuloma formation and tissue fibrosis and is thought to be an initiator of cytokine related inflammation states by inducing other inflammatory cytokines, including IL-1 $\beta$, IL-6, IL-8 and GM-CSF (Baumgartner et al., 1994; Arend and Dayer, 1995). IL-6 is a pleiotropic inflammatory cytokine produced by $\mathrm{T}$ cells, monocytes and macrophages and its local accumulation is associated with a local allergic reaction (Snick, 1990). IL-8 acts on surrounding cells such as neutrophils, T-lympocytes and eosinophils and mediates the migration of neutrophils to local inflammation as a potent activator and chemoattractant of neutrophils (Karakurum et al., 1994; Sengupta et al., 2004). Histamine inducing by cross-linking of the Fc\&RI is an important mediator in immediatetype allergic inflammatory reaction (anaphylactic allergic reaction) (Kemp and Lockey, 2002). In our study, EH had little effect on compound 48/80induced systemic anaphylactic allergic reaction (data not shown). Stimulation of mast cells with 
compound 48/80 initiates the activation of signaltransduction pathway, which leads to histamine release (Mousli et al., 1990). We speculated that EH had no effect on compound 48/80-induced histamine release from mast cells. Previous studies reported that aucubin inhibits TNF- $\alpha$ and IL-6 expression and scopoletin inhibits TNF- $\alpha$, IL- 6 and IL-8 expression through blockade of NF- $\mathrm{kB}$ activation, though it does not affect the release of histamine in mast cells (Jeong et al., 2002; Moon et al., 2006). Sulfasalazine, aucubin and scopoletin, which are potent and specific inhibitor of NF- $\mathrm{KB}$ activation without preventing AP-1 binding activity (Schoonbroodt et al., 1997; Wahl et al., 1998; Jeong et al., 2002). We also may speculate that $\mathrm{EH}$ can be a specific NF- $\mathrm{B} B$ inhibitor. Further study is necessary to demonstrate the accurate role of $\mathrm{EH}$ in the activation of mast cells.

The release of various inflammatory cytokines is regulated by transcription factors, NF- $\mathrm{kB}, \mathrm{AP}-1$, nuclear factor activated T cell, NF-IL6 and hypoxia inducible factor-1 (Rao, 1994; Galien et al., 1996; Fiorini et al., 2000; Jeong et al., 2003). NF-кB is consisted of predominantly two proteins, p50 and p65, also called RelA and cRel, respectively (Baeuerle and Baltimore, 1996). ІкB kinase family contained IKK $\alpha$ (IKK-1) and IKK $\beta$ (IKK-2) is encoded on separate chromosomes and appears to regulate IкB phosphorylation in immortalized cell line and tumor cells. The IкB phosphorylation triggers proteolytic degradation. NF- $\mathrm{\kappa B}$ released from I $\mathrm{\kappa B}$ is translocated into the nucleus to bind the $\kappa \mathrm{B}$ binding sites in the promoter regions of target inflammatory genes subsequently (DiDonato et al., 1997; Regnier et al., 1997; May and Ghosh, 1997; Hu and Wang, 1998). Present study is suggested that EH inhibits the translocation of NF-kB from the cytoplasm to the nucleus and IkB $\alpha$ degradation and phosphorylation. Further study is necessary to demonstrate the accurate role of $\mathrm{EH}$ in the activation of mast cells via $\mathrm{p} 38$ pathway and ERK1/2 pathway and identify active constituents from $\mathrm{EH}$ in inflammatory reaction.

In certain reports, $\mathrm{EH}$ was demonstrated that its effect on experimatal hyperlipemia in rats (Xu et al., 1993). Another paper showed that EH had inhibitory effect of cyclooxygenase (COX-2) and nitric oxide synthase (iNOS) in RAW 264.7 macrophage cells (Hong et al., 2002). In this research, we have been demonstrated that EH inhibits the TNF- $\alpha$, IL- 6 and IL-8 expression in PMA and A23187 stimulated HMC- 1 and EH inhibits the translocation of NF- $\mathrm{KB}$ to the nucleus and $\mathrm{I} \kappa \mathrm{B} \alpha$ degradation and phosphorylation to attenuate secretion of pro-inflammatory cytokines consequently.

In conclusion, the results obtained in this study present that $\mathrm{EH}$ might contributes significantly to the prevention or treatment of mast-cell mediated inflammatory diseases and $\mathrm{EH}$ has potential use in the therapy of chronic allergic inflammation.

\section{ACKNOWLEDGEMENTS}

This work was supported by the Grant of the Korean Ministry of Education, Science and Technology (The Regional Core Research Program/Center for Healthcare Technology Development) and by the Research Grant from Woosuk University.

\section{REFERENCES}

Annelie M, Undine L, Bietlinde L, Gerd k, Katrin H, Pia W, Dirk S, Thomas R, Thomas L, Beate MC. (1993) Human mast cells produce IL-8. J. Immunol. 151, 3261-3266.

Arend WP, Dayer JM. (1995) Inhibition of the production and effects of interleukin-1 and tumor necrosis factor alpha in rheumatoid arthritis. Arthritis Rheum. 38, 151-160.

Azzolina A, Bongiovanni A, Lampiasi N. (2003) Substance $\mathrm{P}$ induces TNF-alpha and IL-6 production through NF kappa B in peritoneal mast cells, Biochim. Biophys. Acta 1643, 75-83.

Baeuerle PA, Baltimore D. (1996) NF-kappa B: ten years after. Cell 87, 13-20.

Baeuerie PA, Henkel T. (1994) Function and activation of NF-êB in the immune system. Annu. Rev. Immu. 12, 141-179.

Baumgartner RA, Yamada K, Deramo VA, Beaven 
MA. (1994) Secretion of TNF- $\alpha$ from a rat mast cell line is a brefeldin A-sensitive and a calcium/protein kinase C-regulated process. J. Immunol. 153, 26092617.

Beaven MA, Metzger H. (1993) Signal transduction by Fc receptors: the Fc epsilon RI case. Immunol. Today 14, 222-226.

Church MK, Levi-Schaffer F. (1997) The human mast cell. J. Allergy Clin. Immunol. 99, 155-160.

Collart MA, Baeuerle P, Vassaili P. (1990) Regulation of tumor necrosis factor alpha transcription in macrophages: involvement of four $\kappa B-$ like motifs and of constitutive and inducible forms of NF- $\kappa B$. Mol. Cell. Biol. 10, 1498-1506.

DiDonato JA, Hayakawa M, Rothwarf DM, Zandi E, Karin M. (1997) A cytokine-responsive IкB kinase that activates the transcription factor NF- $\mathrm{B}$. Nature 388, 548-554.

Ershler WB, Keller ET. (2000) Age-associated increased interleukin-6 gene expression, late-life disease, and frailty. Annu. Rev. Med. 51, 245-270.

Fiorini E, Marchisio PC, Scupoli MT, Poffe O, Tagliabue E, Brentegani M, Colombatti M, Santini F, Tridente G, Ramarli D. (2000) Adhesion of immature and mature $\mathrm{T}$ cells induces in human thymic epithelial cells (TEC) activation of IL-6 gene trascription factors (NF-kappaB and NF-IL6) and IL-6 gene expression: role of alpha3beta1 and alpha6beta4 integrins. Dev. Immunol. 7, 195-208.

Galien R, Evans HF, Garcia T. (1996) Involvment of CCAAT/enhancer-binding protein and nuclear factorkappa B binding site in interleukin-6 promoter inhibition by estrogens. Mol. Endocrinol. 10, 713-722.

Galli SJ. (1993) New concepts about the mast cell. New Engl. J. Med. 328, 257-265.

Galli SJ, Kalesnikoff J, Grimbaldeston MA, Piliponsky AM, Williams CM, Tsai M. (2005) Mast cells as "tunable" effector and immunoregulatory cells: recent advances. Annu. Rev. Immunol. 23, 749-786.

Galli SJ, Zsebo KM, Geissler EN. (1994) The kit ligand, stem cell factor. Adv. Immunol. 55, 1-96.

GrimmS, Baeuerle PA. (1993) The inducible transcription factor NF- $\kappa$ B: structure-function relationship of its protein subunits. Biochem. J. 290, 297-308.

Hide I, Toriu N, Nuibe T, Inoue A, Hide M, Yamamoto S, Nakata Y. (1997) Suppression of TNF-alpha secretion by azelastine in a rat mast (RBL-2H3) cell line: evidence for differential regulation of TNF-alpha release, transcription, and degranulation. J. Immunol. 159, 2932-2940.

Hong CH, Hur SK, Oh OJ, Kim SS, Nam KA, Lee SK. (2002) Evaluation of natural products on inhibition of inducible cyclooxygenase (COX-2) and nitric oxide synthase (iNOS) in cultured mouse macrophage cells. J. Ethnopharmacol. 83, 153-159.

Hosoda M, Yamaya M, Suzuki T, Yamada N, Kamanaka M, Sekizawa K, Butterfield JH, Watanabe T, Nishimura H, Sasaki H. (2002) Effects of rhinovirus infection on histamine and cytokine production by cell lines from human mast cells and basophils. J. Immunol. 169, 1482-1491.

Hu MCT, Wang Y. (1998) IкB kinase- $\alpha$ and $-\beta$ genes are coexpressed adult and embryonic tissues but localized to different human chromosomes. Gut 222, 31-40.

Jeong HJ, Chung HS, Lee BR, Kim SJ, Yoo SJ, Hong SH, Kim HM. (2003) Expression of proinflammatory cytokines via HIF-1alpha and NF-kappaB activation on desferrioxamine-stimulated HMC-1 cells. Biochem. Biophys. Res. Commun. 306, 805-811.

Jeong HJ, Koo HN, Na HJ, Kim MS, Hong SH, Eom JW, Kim KS, Shin TY, Kim HM. (2002) Inhibition of TNF-alpha and IL- 6 production by Aucubin through blockade of NF-kappaB activation RBL-2H3 mast cells. Cytokine 18, 252-259.

Jeong HJ, Lee SA, Moon PD, Na HJ, Park RK, JY, Kim HM, Hong SH. (2006) Alginic acid has anti-anaphylactic effects and inhibits inflammatory cytokine expression via suppression of nuclear factor-kappaB activation. Clin. Exp. Allergy 36, 785-794.

Karakurum M, Shreeniwas R, Chen J, Pinsky D, Yan SD, Anderson M, Sunouchi K, Major J, Hamilton T, Kuwabara K, Rot A, Nowygrod R, Stern D. (1994) Hypoxic induction of interleukin-8 gene expression in human endothelial cells. J. Clin. Invest. 93, 15641570.

Kemp SF, Lockey RF. (2002) Anaphylaxis: a review of causes and mechanisms. J. Allergy Clin. Immunol. 110, 341-348.

Kim HM, Lee YM. (1999) Role of TGF-beta 1 on the IgE-dependent anaphylaxis reaction. J. Immunol. 162, 4960-4965.

Kim MS, Na HJ, Han SW, Jin JS, Song UY, Lee EJ, Song BK, Hong SH, Kim HM. (2003) Forsythia fructus 
inhibits the mast-cell-mediated allergic inflammatory reactions. Inflammation 27, 129-135.

Krishnaswamy G, Ajitawi O, Chi DS. (2006) The human mast cell: an overview. Methods Mol. Biol. 315, 13-34.

Lee SI et al. (1995) Oriental Herb Medicine Bonchohak. Young-lim's publications 157-158.

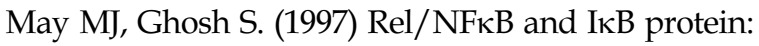
an overview. Semin. Cancer Biol. 8, 63-73.

Metcalfe DD, Baram D, Mekori Ya. (1997) Mast cells. Physiol. Rev. 77, 1033-1079.

Moon PD, Lee BH, Jeong HJ, An HJ, Park SJ, Kim HR, Ko SG, Um JY, Hong SH, Kim HM. (2007) Use of scopoletin to inhibit the production of inflammatory cytokines through inhibition of the IkappaB/NFkappaB signal cascade in the human mast cell line HMC-1. Eur. J. Pharmacol. 555, 218-225.

Mousli M, Bronner C, Bockaert J, Rouot B, Landry Y. (1990) Interaction of substance $P$, compound 48/80 and mastoparan with the alpha-subunit C-terminus of G protein. Immunol. Lett. 25, 355-357.

Rao A. (1994) NF-ATp: a transcription factor required for the co-ordinate induction of several cytokine genes. Immunol. Today 15, 274-281.

Regnier CH, Song H, Gao H, Goeddel DV, Cao Z,
Rothe M. (1997) Identification and characterization of an IкB kinase. Cell 90, 373-383.

Schoonbroodt S, Legrand-Poels S, Best-Belpomme M, Piette J. (1997) Activation of the NF-kappaB transcription factor in a T-lymphocytic cell line by hypochlorous acid. Biochem. J. 321, 777-785.

Sengupta B, Banerjee A, Sengupta PK. (2004) Investigations on the binding and antioxidant properties of the plant flavonoid fisetin in model biomembranes. FEBS Lett. 570, 77-81.

Snick J. (1990) Interleukin-6: an overview. Annu. Rev. Immunol. 8, 253-278.

Tetlow LC, Woolley DE. (1995) Distribution, activation and tryptase/chymase phenotype of mast cells in the rheumatoid lesion. Ann. Rheum. Dis. 54, 549-555.

Thanos D, Maniatis T. (1995) NF-кB: a lesson in family values. Cell 80, 529-532.

Wahl C, Liptay S, Adler G, Schmid RM. (1998) Sulfasalazine: potent and specific inhibitor of nuclear factor kappa B. J. Clin. Invest. 101, 1163-1174.

Xu CF, Bian XY, Qu SM, You LH, Qi ZM, Cheng W, Liu XJ, Liu WZ, Ren SJ. (1993) Effect of Equisetum hyemale on experimental hyperlipemia in rats and its toxic test. Zhongguo Zhong Yao Za Zhi 18, 52-53, 64. 